\title{
Novitates
}

PUBLISHED BY THE AMERICAN MUSEUM OF NATURAL HISTORY CENTRAL PARK WEST AT 79TH STREET, NEW YORK, NY 10024 Number 3296, 11 pp., 8 figures

April 25, 2000

\section{A New Interpretation of the Oldest Fossil Bee (Hymenoptera: Apidae)}

\author{
MICHAEL S. ENGEL ${ }^{1}$
}

\begin{abstract}
The oldest fossil bee, "Trigona" prisca (Apidae: Meliponini), in Late Cretaceous (Maastrichtian) amber from New Jersey, is redescribed and figured. Differences between T. prisca and extant Trigona are noted and the fossil is transferred into a new genus, Cretotrigona. An exploratory cladistic analysis of the Meliponini is undertaken and Cretotrigona supported as sister to the African genus Dactylurina. Affinities between Cretotrigona and recent genera are discussed as are implications of the presence of this derived stingless bee group at the end of the Mesozoic.
\end{abstract}

\section{INTRODUCTION}

At some time during the 1920 s or 1930 s the late Alfred C. Hawkins discovered a piece of amber in Kinkora, New Jersey. The piece was given to Columbia University and was eventually transferred in the 1980s to the $\mathrm{AMNH}$ where it was examined and the fossils contained within were studied for the first time. By far the largest and most complete specimen among the insects preserved in the block was a remarkable bee. The bee was recognized as a member of the corbi- culate apine tribe Meliponini (a.k.a., the stingless bees); it was astonishingly similar to living species of the genus Trigona, and was therefore proposed as Trigona prisca (Michener and Grimaldi, 1988a). This fossil was most significant for it was the oldest record of bees, moving the earliest discovered bee back from $45 \mathrm{Ma}$ (middle Eocene) to approximately $65 \mathrm{Ma}$ (see discussion of dating under Methods below). Not only this, but $T$. prisca was representative of a species in a derived tribe, in a derived subfamily, in the most derived family of Apoidea, indicating

${ }^{1}$ Research Scientist, Division of Invertebrate Zoology, American Museum of Natural History. 
that the diversification of bees had taken place much earlier than was previously believed.

The stingless bees are readily distinguished from other corbiculate Apinae by the combination of reduced forewing venation, the presence of a jugal lobe in the hind wing, the absence of an anterior prong on the strigilis, the absence of metatibial spurs, the presence of a penicillum, the absence of an auricle, the simple claws, the presence of an arolia, and the reduced sting. Of these features, nearly all are visible in $T$. prisca; the only characters not possible to confirm are the reduction of the sting and the presence of the jugal lobe at the base of the hind wing. Although the phylogenetic position of the Meliponini has been the subject of recent debate based on limited molecular data sets (e.g., Koulianos et al., 1999; Mardulyn and Cameron, 1999), the most well-supported topology, derived from a combination of morphological and molecular evidence (Chavarría and Carpenter, 1994; Schultz et al., 1999), places them as sister to the honey bees (Apini), with the bumble bees (Bombini) and orchid bees (Euglossini) being more basal. Paleontological evidence from the diverse Baltic amber bee fauna also favors this topology (Engel, 1998b, in prep.). The internal phylogeny of Meliponini has been most recently studied by Michener (1990) with additions and modifications to his study presented by Camargo and Pedro (1992) (see also below). The internal phylogenies of the other corbiculate tribes have been examined by Engel and Schultz (1997) and Engel (1998a, 1999b) for Apini; by Williams $(1985,1994)$ and Chen and Wang (1997) for Bombini; and by Kimsey (1987) and Engel (1999a) for Euglossini.

Below I provide new character information pertinent to the systematic position of this enigmatic fossil bee. A preliminary phylogenetic analysis of meliponine relationships is also undertaken in order to gain an insight into the affinities of this Cretaceous species with extant stingless bees. Together these data suggest that $T$. prisca should be removed from Trigona, and it is therefore transferred into a new genus. This work is part of an ongoing series designed to monograph the fossil bees of the world.

\section{ACKNOWLEDGMENTS}

I am grateful to David A. Grimaldi for allowing me to study this fossil, for further preparing the amber piece so that the bee was more easily visible, and for providing the habitus illustration presented here as figure 7, and to Michael Rothman for allowing me to reproduce his wonderful reconstruction of the fossil here as figure 6. Both Molly G. Rightmyer and Tam C. Nguyen gave valuable assistance in the computerized construction of the color plate; I am thankful for their expertise and patient assistance. Robert W. Brooks, James M. Carpenter, Charles D. Michener, and Molly G. Rightmyer read the manuscript and provided constructive critiques. Support for this work was provided by Robert G. Goelet, Chairman Emeritus of the American Museum of Natural History Board of Trustees.

\section{METHODS}

The age of $T$. prisca has been somewhat controversial. Michener and Grimaldi (1988a, 1998b) originally considered the amber to be Campanian (ca. $80 \mathrm{Ma}$ ) in origin based on chemical comparison with other New Jersey ambers. Rasnitsyn (in Rasnitsyn and Michener, 1990), however, expressed doubt over a Cretaceous age of the amber owing to the identity of the other insect inclusions that he felt were of a Tertiary age at best (perhaps Paleocene). Recently, Grimaldi (1999) presented critical evidence for a Late Cretaceous origin of the amber containing $T$. prisca. It therefore appears that this fossil can be placed with certainty in the Mesozoic, although near the end of this era; its age is treated as Late Maastrichtian (ca. 65-70 Ma) herein. Stratigraphy of New Jersey amber sites has been reviewed by Grimaldi et al. (1989) and Grimaldi et al. (2000).

Morphological terminology follows that proposed by Michener (1944) with specific additions for meliponine bees as presented by Michener (1990). The abbreviations F, $\mathrm{OD}, \mathrm{S}$, and T are used for flagellomere, ocellar diameter (based on the median ocellus), metasomal sternum, and metasomal tergum, respectively. In the generic description, particularly noteworthy features are presented in boldface. 
A cladistic analysis of the Meliponini was undertaken to explore the affinities of T. prisca with living stingless bee genera. The data and classification of Michener (1990) were used and readers should refer to his study for the complete matrix and character descriptions. The line of code for $T$. prisca in Michener's matrix comes out as: 02211?????????001. Only one character addition was made to Michener's matrix; this being character $A$ from Camargo and Pedro (1992) and is as follows: Basal sericeous area on inner surface of metabasitarsus, (0) absent, or (1) present. All genera were coded as absent for this character except Trigona and the fossil. The final matrix was constructed in DADA (Nixon, 1995) and analyzed using the $m h^{*}$ and $b b^{*}$ commands in Hennig86 (Farris, 1988); the resulting tree was visualized using CLADOS (Nixon, 1993). A single topology resulted of length 42, CI 0.52, and RI 0.80 (fig. 8). Details and implications of the tree are discussed below (Discussion).

\section{SYSTEMATIC PALEONTOLOGY}

\section{Cretotrigona, new genus}

TYPe SPECIES: Trigona (Trigona) prisca Michener and Grimaldi, 1988a.

DiAgNOSIS: The new genus is very similar to Trigona as is evidenced by the presence of a basal sericeous area on the inner surface of the metabasitarsus (see also Discussion, below), the broadly depressed posterior marginal area on the inner surface of the metatibia, the apical bend in vein $M$ of the forewing at about the position where $1 \mathrm{~m}$-cu would be located, the bare compound eyes, and the absence of a preoccipital carina. It differs from this group by the short, tapering hairs of the rastellum (more similar to those of the African Dactylurina), the entirely simple hairs of the metatibial posterior margin [although this is similar to those of the southeast Asian Trigona (Lepidotrigona)], and the absence of hairs on the surface of the corbicula. It is further separated from Trigona (excluding the subgenera Lepidotrigona and Papuatrigona) by the weak and gentle slope of the keirotrichiate median zone from the posterior marginal zone on the inner surface of the metatibia. See Discussion (below) for further consideration of the fossil's similari- ties and differences with extant Trigona and its cladistic relationship with Dactylurina.

DESCRIPTION: Worker. Integument black and without yellow markings. Head about as wide as mesosoma; gena slightly narrower than compound eye in lateral view (fig. 7); frontal line a weakly impressed line; frons gently convex; antennal sockets set just below midline of face; scape short, not reaching to median ocellus; face with minute punctures, separated by a puncture width; just above level of antennal sockets punctures become more sparse (figs. 3, 4), separated by two to three times puncture width; integument between smooth and shining. Clypeus relatively flat with widely scattered, faint, coarse punctures; about two times wider than long; apical margin straight; slightly projecting below lower tangent of compound eyes; epistomal sulcus weakly incurved apicolaterally. Mandible with three teeth on lower half of apical margin, teeth strong and pointed, particularly deep incision between uppermost tooth and upper half of mandible; upper half gently concave with weakly defined upper angle. Malar space short, less than $0.5 \mathrm{OD}$ in length. Vertex with minute punctures separated by puncture width, integument between faintly imbricate; vertex strongly procurved behind ocelli, rounded [not sharply procurved; e.g., Cephalotrigona capitata (Smith, 1854)], neither ridged nor produced; preoccipital carina absent; ocelloccipital distance less than 0.5 OD. Interocellar distance less than ocellocular distance; maximal separation between compound eyes slightly greater than length of compound eye; compound eyes bare; inner margin of compound eye straight (figs. 1-3); compound eyes converging below. Mesosoma without punctures, integument faintly imbricate, pubescence simple and fuscous; tegula with faint punctures separated by less than a puncture width; integument between faintly imbricate; scutellum rounded and rather thick in lateral view, slightly projecting posteriorly over propodeum (fig. 7). Metatibia gently expanded, not broadly spoon-shaped (e.g., Lepidotrigona or Partamona) (fig. 7); surface of corbicula gently concave, without hairs; posterior margin of metatibia without plumose hairs, hairs simple over entire length of margin (fig. 7); elevated keirotrichiate 


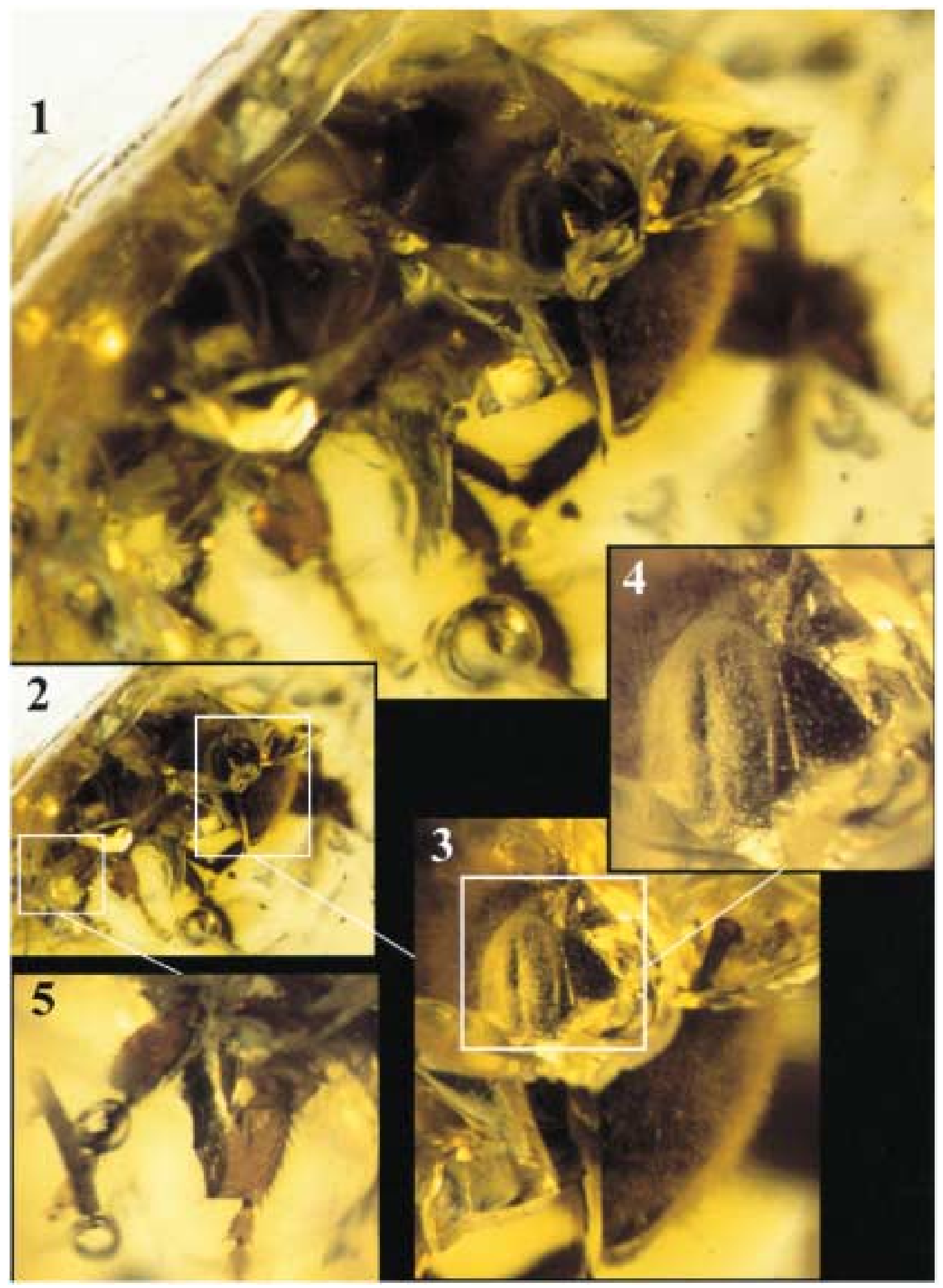




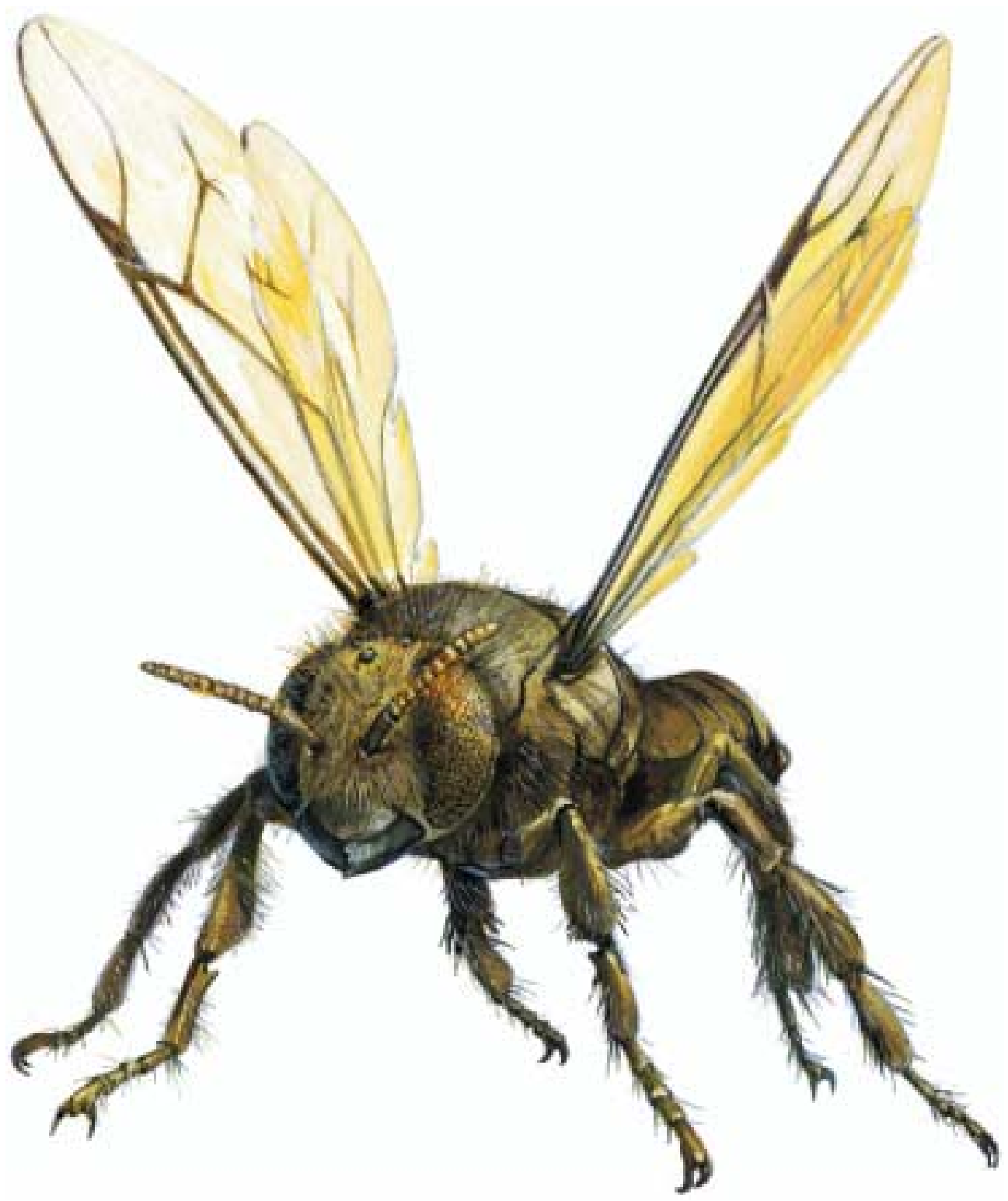

Fig. 6. Artist's reconstruction of Cretotrigona prisca as it might have appeared in flight (painting courtesy of Michael Rothman).

$\leftarrow$

Figs. 1-5. Photomicrographs of holotype worker of Cretotrigona prisca (AMNH C88720: Photographs by the author). 1. Right lateral habitus. 2. Miniature of right lateral habitus indicating areas of magnification. 3. Magnified oblique view of face; white square indicates area of further magnification. 4. Magnified view of right compound eye showing sculpturing of integument near eye. 5. Magnified view of metabasitarsi and flagellar fragment. 
median zone of inner surface of metatibia separated from shining posterior margin by weak and gentle slope; posterior apical angle slightly acute and prominent; rastellum composed of short, tapering hairs; penicillum strong. Basal sericeous area of inner surface of metabasitarsus present (figs. 5, 7); claws simple; arolium present and relatively large (fig. 7). Forewing extending well beyond metasomal apex; basal vein basad cu-a by about $1 \frac{1}{2}$ times vein width; $M$ bent at point where it would typically meet $1 \mathrm{~m}-\mathrm{cu}$; submarginal angle slightly acute; without indication of submarginal cells, not even by nebulous or infumate veins; marginal cell apex closed at wing apex, pointed. Propodeum strongly declivitous (fig. 7); basal area poorly defined; without pubescence. Metasoma greatly reduced (fig. 7), narrower than mesosoma; T1 slightly broader than long.

ETYMOLOGY: The new genus-group name is derived from Cretaceous and Trigona, the genus of meliponine bees in which the fossil was originally placed. The gender of the name is feminine.

\section{Cretotrigona prisca (Michener and Grimaldi), new combination \\ Figures 1-7}

Trigona (Trigona) prisca Michener and Grimaldi, 1988a: 5.

Diagnosis: As for the genus.

DESCRIPTION: As described for the genus with the following additions: Worker (queen and drone unknown). Total body length 5.6 $\mathrm{mm}$; forewing length $5.3 \mathrm{~mm}$. Head length $2.1 \mathrm{~mm}$, width $2.2 \mathrm{~mm}$. Upper interorbital distance $1.6 \mathrm{~mm}$, lower interorbital distance $1.2 \mathrm{~mm}$; compound eye length $1.5 \mathrm{~mm}$. Scape length $0.9 \mathrm{~mm}$. Metatibial length 2.1 $\mathrm{mm}$; maximum width $0.7 \mathrm{~mm}$. Metabasitarsus length $1.0 \mathrm{~mm}$; width $0.5 \mathrm{~mm}$.

Integument dully shining on head (figs. 3, 4), otherwise not apparently shining; head, mesosoma, and metasoma apparently black without yellow markings. Gena faintly imbricate. Mesoscutum and scutellum apparently finely imbricate and impunctate. Pleura imbricate and impunctate. Corbicula glabrous. Legs dark brown. Wing membrane hy- aline; veins faintly amber. Metasoma finely imbricate and impunctate.

Pubescence generally fuscous and simple. Face with scattered setae approximately 0.5 $0.75 \mathrm{OD}$ in length; hairs on vertex longer (1 OD) and more numerous and stout than those of face; hairs of gena like those of face although slightly more numerous. Mesoscutum with hairs like those of face; those of scutellum as on mesoscutum although slightly longer along posterior margin; tegula with hairs as on mesoscutum although restricted to apical half; pleura with long (1.5-2 OD) scattered hairs; hypoepimeron with shorter hairs (0.75 OD) restricted to upper third or half. Metasoma apparently with sparse pubescence, those of S1-3 approximately $1.25-1.5$ OD in length.

HolotyPE: Worker, Late Cretaceous (Maastrichtian) amber, Kinkora, Burlington County, New Jersey, A. C. Hawkins (AMNH C88720); deposited in the amber fossil collection, Division of Invertebrate Zoology, AMNH.

PRESERVATION: The piece of amber in which the bee is preserved is transparent light-yellow with dimensions of approximately $1.2 \mathrm{~cm} \times 1.7 \mathrm{~cm} \times 1.2 \mathrm{~cm}$. The piece contains, aside from the bee, individuals (either partial or complete) of Acari, Coleoptera (Curculionidae), Diptera (Cecidomyiidae, Milichiidae, and Phoridae), Heteroptera (Reduviidae), Hymenoptera (Scelionidae, Mymarommatidae), and Isoptera. Of these, only the bee and one of the phorids (Grimaldi, 1989) have been studied by systematists and described. The fragile amber piece has been embedded in epoxy to protect it from further deterioration (method described in Nascimbene and Silverstein, 2000). The support and stability that the epoxy provides to the piece allowed for one side to be minutely trimmed and polished to expose a new, small "window" on the right side of the bee.

The bee is, for the most part, intact (figs. $1,7)$. The antennae are broken beyond the scapes with fragments of the flagella present in the amber near the bee (e.g., figs. 1, 5, 7). Also the distal tarsal segments of some legs are missing and one wing is slightly torn along its length. Outside of these few areas there is no damage from compression. The 


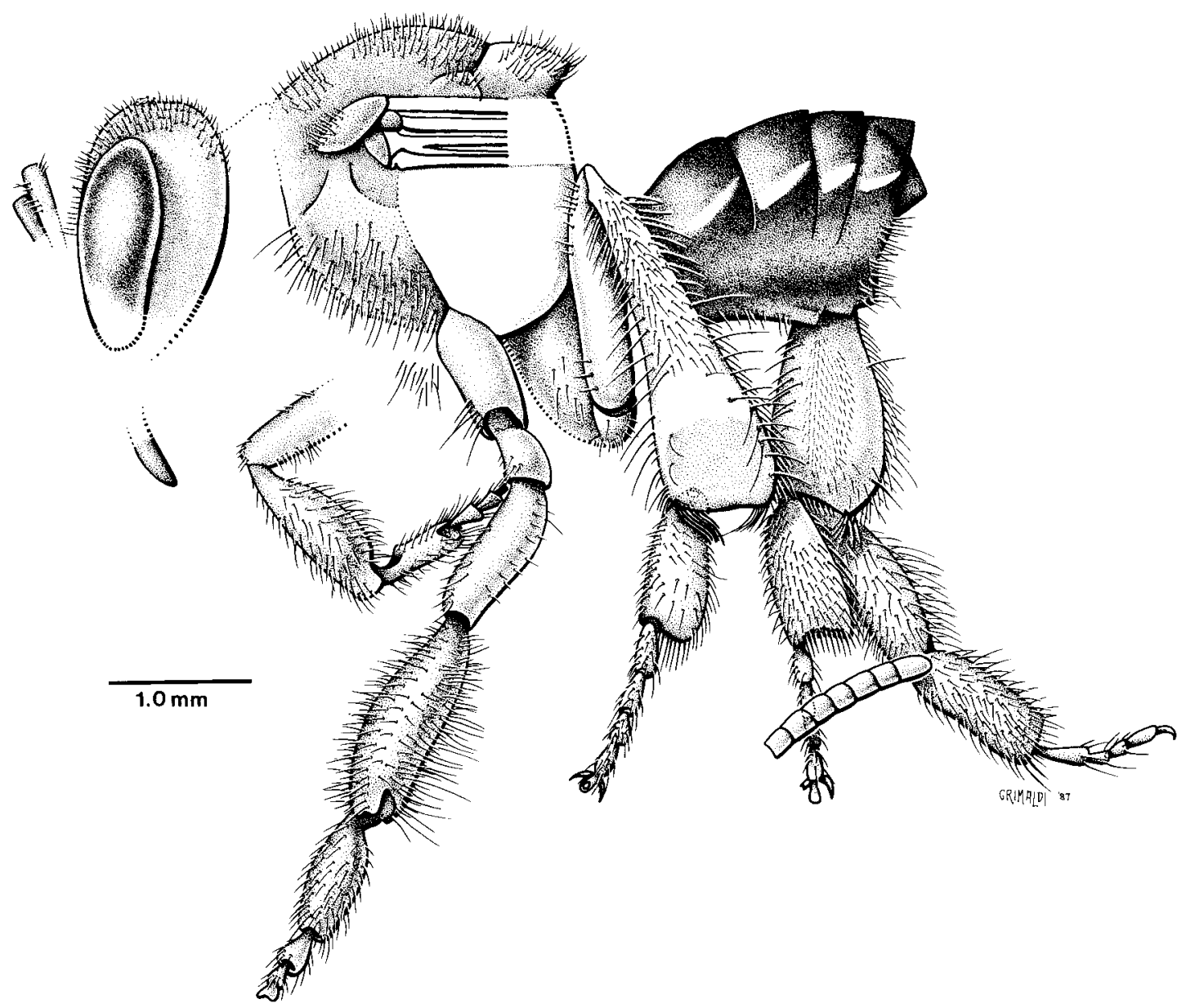

Fig. 7. Left lateral habitus illustration of holotype worker of Cretotrigona prisca (illustration courtesy of D. A. Grimaldi, AMNH).

bee is positioned with its dorsum near the upper surface of the block and its anterior end slightly dipping downward into the amber. The wings are folded over the dorsum, the left wing being slightly bent toward the upper left side of the mesosoma and metasoma, while the right forewing is somewhat torn just below its midpoint. The legs are extended below the bee into the amber (figs. 1, $2,7)$. There is some Schimmel on the basal half of the right forewing as well as a bit on the face.

Interestingly, near the surface of the newly cut "window" on the left side of the block just at its midpoint, a fragment of a third forewing (its apical half only) suggests that at least one other bee was involved in the struggle with the sap that claimed the life of the holotype. Whether the second bee escaped its nestmate's fate, merely losing a portion of its forewing, remains a mystery.

\section{DISCUSSION}

Among genera of Meliponini, Cretotrigo$n a$ is phenetically most similar to Trigona. The basal sericeous area on the inner surface of the metabasitarsus is a distinctive feature of Trigona species and its presence in Cretotrigona suggests some relationship between these genera. Cretotrigona, however, differs most readily in the absence of plumose hairs along the posterior margin of the metatibia, the gentle slope separating the el- 
evated keirotrichiate median zone of the metatibia from the posterior marginal zone, and the complete absence of any indication of submarginal cells in the forewing. The subgenus Lepidotrigona, from Southeast Asia, is the only group of Trigona to also lack plumose hairs and this feature has often been used to argue for its status as a genus separate from Trigona (e.g., Moure, 1961). Lepidotrigona, along with the monotypic subgenus Papuatrigona, also lacks the abrupt slope separating the keirotrichiate median zone from the posterior marginal zone on the metatibia found in other Trigona species. Outside of these two characters, though, Cretotrigona has no affinity to Lepidotrigona, the former lacking the broadly expanded and spoon-shaped metatibia and the densely plumose hairs of the mesoscutal margins, among other features. The short, tapering hairs of the rastellum also differ from the stronger and more blunt-ended bristles of Trigona sensu lato. In the fossil this feature is similar to the state seen in the African genus Dactylurina, a group superficially very similar to Trigona, ${ }^{2}$ where the rastellar bristles are also soft and tapering, although certainly longer than in Cretotrigona. Interestingly, one species of Dactylurina also has a weakly developed sericeous area on the basal inner surface of the metabasitarsus. Thus, as implied by Michener (1990), the fossil is not without possible affinities to this African genus of stingless bees. These observations are made all the more significant by the realization that New Jersey and Africa were, in the Late Cretaceous, not far from one another. The character matrix of Michener (1990) was used for genera of Meliponini, supplemented by a single character from Camargo and Pedro (1992: see Methods above), to find that Cretotrigona shared a cladistic relationship with Dactylurina (fig. 8).

This fossil is the oldest record of eusocial behavior among the Apoidea (Michener and Grimaldi, 1988b). Cretotrigona prisca is represented by a female of the worker caste. In workers of highly eusocial bees the metasoma frequently shrinks owing to the reduction of the ovaries; a feature seen in the fossil (fig.

\footnotetext{
${ }^{2}$ Dactylurina was even originally proposed as a subgenus of Trigona (Cockerell, 1934).
}

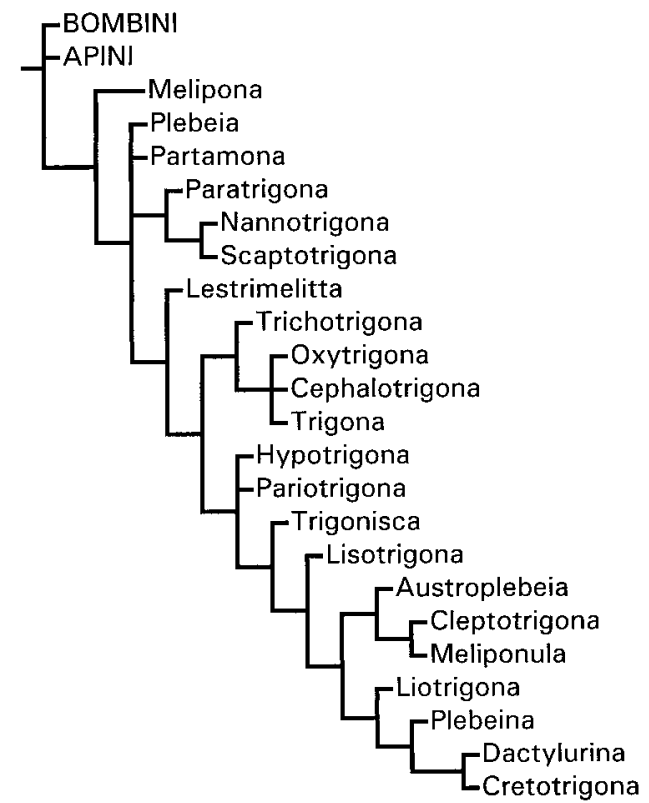

Fig. 8. Exploratory phylogeny of tribe Meliponini (length 42 , CI 0.52 , RI 0.80).

7). Similarly, the phylogenetic placement of this species in the Meliponini, regardless of its generic assignment, suggests that it was highly eusocial. All members of the Meliponini, except the socially parasitic genera Lestrimelitta and Cleptotrigona, are highly eusocial, as are species of their sister tribe, Apini. The fixation of this biological trait across a monophyletic Apini + Meliponini implies that the common ancestor of these two tribes was similarly eusocial (Schultz et al., 1996). The presence of primitive eusociality among the Bombini, sister group to the Apini + Meliponini clade, suggests that general eusociality is even older. Thus, both morphological and phylogenetic evidence supports the reconstruction of an advanced eusocial lifestyle for this ancient species of stingless bee. Like most living meliponines, this bee probably constructed nests in preexisting cavities or externally with surrounding batumen sheets, thereby creating an artificial cavity. A relationship with the enigmatic Dactylurina (fig. 8), however, leaves unanswered questions about finer details of Cretotrigona nest construction. Species of Dactylurina are unique among living Meliponini; species construct vertical combs con- 
sisting of two layers of horizontally oriented cells (Darchen and Pain, 1966), similar in this respect to nests of Apis. Thus, whether Cretotrigona produced nests typical of other Meliponini or shared a vertical comb construction with Dactylurina, remains unknown.

Cretotrigona prisca is presently the oldest bee from the geological record. Earlier accounts of bees were based on misidentifications. The Early Cretaceous "bee" described by Hong (1983) is actually a sphecid wasp (Darling and Sharkey, 1990; Engel, 1998a, 1999 b, in prep.) and has been synonymized with the genus Archisphex (Rasnitsyn et al., 1998). Likewise, the fossil reported as a "native bee" by Carroll (1962) from the Jurassic of Australia lacks wings, a complete head, and, in fact, any characters that could place it within the Aculeata, let alone the Apoidea. Lastly, the reports based on trace fossils of "bee nests" by Hasiotis and Demko (1996) from the Upper Jurassic and Hasiotis [1997: popularized by Wilford (1995)] from the Upper Triassic of North America are actually nests of wasps and wood-boring beetles, respectively (Grimaldi, 1999; Engel, in prep.). Although apoid specimens from the Early Cretaceous of Brazil assigned to the genus Angarosphex ${ }^{3}$ have been implicated as possible early bees or bee ancestors (e.g., Grimaldi, 1999), this no longer seems probable. After briefly examining a few specimens of these fossil wasps in the AMNH, I can confirm their placement among the Apoidea (e.g., presence of a pronotal lobe in previously unstudied, laterally compressed specimens). They can be excluded from the bees, however, by the apparent absence of branched or plumose hairs, absence of a mesotibial comb, the dorsoventral length of the mesocoxa being apparently less than the distance from the mesocoxal summit to the hindwing base, ${ }^{4}$ the metabasitarsus not broader than the following tarsal segments, and cu-a in the hind wing not shorter than

\footnotetext{
${ }^{3}$ These Brazilian taxa were originally proposed as species of Cretosphex (Darling and Sharkey, 1990) but were subsequently transferred to Angarosphex by Rasnitsyn et al. (1998).

${ }^{4}$ It must be noted that some short-tongue bees have a shortened mesocoxa and so this character taken by itself cannot exclude Angarosphex from the bees.
}

the second abscissa of $\mathrm{M}+\mathrm{Cu}$ (other synapomorphies of the bees are not visible in any of the specimens I examined). Although an early bee might not be expected to have all of the distinctive synapomorphies seen among living taxa, these fossils appear to represent a primitive sphecid stock (Rasnitsyn et al., 1999), rather than a derived group that might be implicated in early bee origins. They certainly do not appear to be closely allied with the Crabronidae, the group of sphecids that has been implicated as the nearest relative to the bees (Brothers, 1999; Melo, 1999).

Cretotrigona is the only bee known from the Mesozoic. The fact that this bee is representative of an apparently derived genus of meliponine bees is significant. The Meliponini are already a highly derived tribe of the most derived family of bees (Roig-Alsina and Michener, 1993; Engel, in prep.) implying that the diversification of the bees, at least at higher levels, had already taken place by the end of the Cretaceous. This is also consistent with the presence of plants that are strongly associated with derived apine bees for pollination in Late Cretaceous (Turonian, ca. $90 \mathrm{Ma}$ ) deposits of the same area as Cretotrigona (e.g., Crepet and Nixon, 1998). The origin and rapid, higher diversification of the bees likely took place sometime shortly after the origin of Angiosperms in the early mid-Cretaceous (Michener, 1979; Engel, 1996, in prep.; Grimaldi, 1999). Hopefully, continued work at Cretaceous amber sites throughout the world (e.g., Lebanon, New Jersey, Siberia) will uncover additional specimens and, perhaps, from more basal bee groups (e.g., Colletidae, Halictidae), thereby providing greater insight into the origin and early diversification of the bees. Until such a time, Cretotrigona stands alone as the only bee from the Age of Dinosaurs.

\section{REFERENCES}

Brothers, D. J.

1999. Phylogeny and evolution of wasps, ants and bees (Hymenoptera, Chrysidoidea, Vespoidea and Apoidea). Zool. Scr. 28: 233-249.

Camargo, J.M.F., and S.R.M. Pedro

1992. Sistemática de Meliponinae (Hymenoptera, Apidae): sobre a polaridade e sig- 
nificado de alguns caracteres morfológicos. In C. da Cruz Landim and J. C. Netto (eds.), Anais do encontro brasileiro sobre biologia de abelhas e outros insetos sociais. Naturalia spec. no.: 4549.

Carroll, E. J.

1962. Mesozoic fossil insects from Koonwarra, South Gippsland, Victoria. Australian J. Sci. 25: 264-265.

Chavarría, G., and J. M. Carpenter

1994. "Total evidence" and the evolution of highly social bees. Cladistics 10: 229258.

Chen, X.-L., and S.-F. Wang

1997. A study on phylogenetic relationships among the subgenera of bumble bees (Hymenoptera: Apidae). Entomol. Sinica 4: 324-336.

Cockerell, T.D.A.

1934. Some African meliponine bees. Rev. Zool. Bot. Afr. 26: 46-62.

Crepet, W. L., and K. C. Nixon

1998. Fossil Clusiaceae from the Late Cretaceous (Turonian) of New Jersey and implications regarding the history of bee pollination. Am. J. Bot. 85: 11221133.

Darchen, R., and J. Pain

1966. Le nid de Trigona (Dactylurina) staudingeri Gribodoi, [sic] (Hymenoptera: Apidae). Biol. Gabonica 2: 25-35.

Darling, D. C., and M. J. Sharkey

1990. Order Hymenoptera. In D. A. Grimaldi (ed.), Insects from the Santana Formation, Lower Cretaceous, of Brazil. Bull. Am. Mus. Nat. Hist. 195: 123-153.

Engel, M. S.

1996. New augochlorine bees (Hymenoptera: Halictidae) in Dominican amber, with a brief review of fossil Halictidae. J. Kansas Entomol. Soc., suppl. 69: 334345.

1998a. Fossil honey bees and evolution in the genus Apis (Hymenoptera: Apidae). Apidologie 29: 265-281.

1998b. Comparative morphology and the phylogeny of the corbiculate bees (Hymenoptera: Apidae; Apinae). Proc. 13th Int. Congr. IUSSI, Adelaide 1998: 151.

1999a. The first fossil Euglossa and phylogeny of the orchid bees (Hymenoptera: Apidae; Euglossini). Am. Mus. Novitates 3272: 14 pp.

1999b. The taxonomy of recent and fossil honey bees (Hymenoptera: Apidae; Apis). J. Hym. Res. 8: 165-196.
Engel, M. S., and T. R. Schultz

1997. Phylogeny and behavior in honey bees (Hymenoptera: Apidae). Ann. Entomol. Soc. Am. 90: 43-53.

Farris, J. S.

1988. Hennig86, Version 1.5. Program and Documentation. Port Jefferson Station, NY.

Grimaldi, D.

1989. The genus Metopina (Diptera: Phoridae) from Cretaceous and Tertiary ambers. J. New York Entomol. Soc. 97: 65-72.

1999. The co-radiations of pollinating insects and angiosperms in the Cretaceous. Ann. Missouri Bot. Gard. 86: 373-406.

Grimaldi, D., C. W. Beck, and J. J. Boon

1989. Occurrence, chemical characteristics, and paleontology of the fossil resins from New Jersey. Am. Mus. Novitates 2948: 28 pp.

Grimaldi, D., A. Shedrinsky, and T. Wampler

2000. A remarkable deposit of fossiliferous amber from the Upper Cretaceous (Turonian) of New Jersey. In D. Grimaldi (ed.), Studies on fossils in amber, with particular reference to the Cretaceous of New Jersey 1-76. Leiden: Backhuys.

Hasiotis, $\mathrm{S}$

1997. Abuzz before flowers. Plateau J. 1: 2127.

Hasiotis, S. T., and T. M. Demko

1996. Terrestrial and freshwater trace fossils, Upper Jurassic Morrison Formation, Colorado Plateau. In M. Morales (ed.), The Continental Jurassic. Mus. Northern Arizona Bull. 60: 355-370.

Hong, Y. C.

1983. New fossil insects of the Laiyang Group from the Laiyang Basin, Shandong Prov. Prof. Pap. Stratigr. Paleontol. 11: 31-41.

Kimsey, L. S.

1987. Generic relationships within the Euglossini (Hymenoptera: Apidae). Syst. Entomol. 12: 63-72.

Koulianos, S., R. Schmid-Hempel, D. W. Roubik, and P. Schmid-Hempel

1999. Phylogenetic relationships within the corbiculate Apinae (Hymenoptera) and the evolution of eusociality. J. Evol. Biol. 12: 380-384.

Mardulyn, P., and S. A. Cameron

1999. The major opsin in bees (Insecta: Hymenoptera): a promising nuclear gene for higher level phylogenetics. Mol. Phylogenet. Evol. 12: 168-176. 
Melo, G.A.R.

1999. Phylogenetic relationships and classification of the major lineages of Apoidea (Hymenoptera), with emphasis on the crabronid wasps. Univ. Kansas Mus. Nat. Hist. Sci. Pap. 14: 1-55.

Michener, C. D.

1944. Comparative external morphology, phylogeny, and a classification of the bees (Hymenoptera). Bull. Am. Mus. Nat. Hist. 82: 151-326.

1979. Biogeography of the bees. Ann. Missouri Bot. Gard. 66: 277-347.

1990. Classification of the Apidae (Hymenoptera). Univ. Kansas Sci. Bull. 54: 75-164.

Michener, C. D., and D. A. Grimaldi

1988a. A Trigona from Late Cretaceous amber of New Jersey (Hymenoptera: Apidae: Meliponinae). Am. Mus. Novitates 2917: $10 \mathrm{pp}$.

1988b. The oldest fossil bee: apoid history, evolutionary stasis, and antiquity of social behavior. Proc. Natl. Acad. Sci. 85: 6424-6426.

Moure, J. S.

1961. A preliminary supra-specific classification of the Old World meliponine bees (Hym., Apoidea). Studia Entomol. 4: $181-242$.

Nascimbene, P., and H. Silverstein

2000. The preparation of fragile Cretaceous ambers for conservation and study of organismal inclusions. In D. Grimaldi (ed.), Studies on fossils in amber, with particular reference to the Cretaceous of New Jersey 93-102. Leiden: Backhuys.

Nixon, K. C.

1993. CLADOS, Version 1.4.88. Program and Documentation. L. H. Bailey Hortorium, Cornell Univ., Ithaca, NY.

1995. DADA, Version 0.96.1. Program and Documentation. Ibid.

Rasnitsyn, A. P., and C. D. Michener

1990. Miocene fossil bumble bee from the Soviet Far East with comments on the chronology and distribution of fossil bees (Hymenoptera: Apidae). Ann. Entomol. Soc. Am. 84: 583-589.

Rasnitsyn, A. P., E. A. Jarzembowski, and A. J. Ross

1998. Wasps (Insecta: Vespida $=$ Hymenoptera) from the Purbeck and Wealden (Lower Cretaceous) of southern England and their biostratigraphical and palaeoenvironmental significance. Cretac. Res. 19: 329-391.

Rasnitsyn, A. P., W. J. Pulawski, and X. MartínezDelclòs

1999. Cretaceous digger wasps of the new genus Bestiola Pulawski and Rasnitsyn (Hymenoptera: Sphecidae: Angarosphecinae). J. Hym. Res. 8: 23-34.

Roig-Alsina, A., and C. D. Michener

1993. Studies of the phylogeny and classification of long-tongued bees (Hymenoptera: Apoidea). Univ. Kansas Sci. Bull. 55: 123-162.

Schultz, T. R., R. B. Cocroft, and G. A. Churchill 1996. The reconstruction of ancestral character states. Evolution 50: 504-511.

Schultz, T. R., M. S. Engel, and M. Prentice

1999. Resolving conflict between morphological and molecular evidence for the origin of eusociality in the "corbiculate" bees (Hymenoptera: Apidae): a hypothesis-testing approach. Univ. Kansas Mus. Nat. Hist. Spec. Publ. 24: 125138.

Smith, F.

1854. Catalogue of hymenopterous insects in the collection of the British Museum, Part 2, Apidae. London: Brit. Mus.

Wilford, J. N.

1995. Which came first: bees or flowers? Find points to bees. New York Times, May 23: $\mathrm{C} 1, \mathrm{C} 11$.

Williams, P. H.

1985. A preliminary cladistic investigation of relationships among the bumble bees (Hymenoptera, Apidae). Syst. Entomol. 10: 239-255.

1994. Phylogenetic relationships among bumble bees (Bombus Latr.): a reappraisal of morphological evidence. Ibid. 19: 327-344. 
Recent issues of the Novitates may be purchased from the Museum. Lists of back issues of the Novitates and Bulletin published during the last five years are available at World Wide Web site http://nimidi.amnh.org. Or address mail orders to: American Museum of Natural History Library, Central Park West at 79th St., New York, NY 10024. TEL: (212) 769-5545. FAX: (212) 7695009. E-MAIL: scipubs@amnh.org

(a) This paper meets the requirements of ANS/ NISO Z39.48-1992 (Pemanence of Paper). 